\title{
Protecting the Groundwater Environment of Tulkarem City of Palestine from Industrial and Domestic Pollution
}

\author{
Amjad Aliewi ${ }^{*}$, Najwan Imseih $^{2}$, Deeb Abdulghafour ${ }^{3}$ \\ ${ }^{1}$ House of Water and Environment, Newcastle University, Newcastle upon Tyne, UK; ${ }^{2}$ House of Water and Environment, Ramallah, \\ Palestine; ${ }^{3}$ Palestinian Water Authority, Ramallah, Palestine. \\ Email: ${ }^{*}$ amjad.aliewi@gmail.com
}

Received August $7^{\text {th }}, 2013$; revised September $6^{\text {th }}, 2013$; accepted October $5^{\text {th }}, 2013$

Copyright (C) 2013 Amjad Aliewi et al. This is an open access article distributed under the Creative Commons Attribution License, which permits unrestricted use, distribution, and reproduction in any medium, provided the original work is properly cited.

\begin{abstract}
Domestic sewage, solid waste, industrial activities, and excessive use of fertilizers and pesticides are the main sources of pollution that threaten the main groundwater aquifers of Tulkarem City of Palestine which add to the problem of water scarcity already experienced by the Palestinians in the West Bank. These aquifers are a vital groundwater resource that provides high quality water. This paper presents the findings of the "Pro Aquifer" project funded by the EU, which aims to reduce groundwater polluting activities in the main municipalities such as Tulkarem. The scientific research of this paper was conducted on the potential and existing sources of groundwater pollution that threaten the Aquifer. GIS tools as well as vulnerability, hazard and risk mapping and pollution modeling were used to examine the impacts of pollution to the groundwater resources in the study area. The local-scale pollution transport model was developed to define the general characteristics of the groundwater flow system as well as to consequently assess the future transport trends of pollution in the groundwater water system of the Tulkarem area. The outputs of this scientific research were used to establish policies and guidelines for reducing water and environmental pollution in Palestinian municipalities. The recommendations produced aim to help Palestinian municipalities prevent pollution of the critical trans-boundary groundwater resources that underlie Tulkarem City. These guidelines provide a methodology to help municipalities begin solving the environmental issues they face. The goals of these guidelines are to protect and prevent further deterioration of the resources of the Mountain Aquifer and to enable and empower municipal officials and staff to achieve these goals.
\end{abstract}

Keywords: Groundwater Pollution; Environmental Protection; Vulnerability Mapping; Groundwater Modelling; Policy Guidelines

\section{Introduction}

The shared groundwater systems of the mountain aquifer are one of the most significant water resources for the residents of the project area. Population growth and economic development, combined with natural water scarcity in the region, have led to significant stresses on these water resources. One of the primary factors that threaten the sustainability of groundwater in the region is pollution from above-ground sources, including domestic sewage, solid waste, industrial activities, and agricultural practices.

The main water resources for Palestinians are currently under threat of pollution. The Mountain Aquifer in the study area has been subject to pollution, leading to clo-

\footnotetext{
${ }^{*}$ Corresponding author.
}

sure of some wells. Unsustainable management practices have acutely worsened the water situation. Pollution by industrial activities sewage has rendered the water of some natural springs in the West Bank undrinkable, and results from monitoring in recent years indicate clearly that pollution has already intruded groundwater in deep wells as well [1]. The future of the already scarce water resources of the Palestinians is thus under severe threat. The majority of polluting activities is in the hands of local municipalities or under their control.

The groundwater environment in the study area may be polluted by a number of contaminants but raw sewage is the most serious one.

To address the protection of Palestinian groundwater resources from pollution, in the context from the unique perspective of local municipalities, Friends of the Earth 
Middle East (FoEME), together with the House of Water and Environment (HWE), with support from Green Cross France and the EU, have conducted a project called "Protecting trans-boundary groundwater sources from pollution ("Pro-Aquifer") since January 2007 [2]. The Pro Aquifer project aims to help municipalities identify polluting activities in their boundaries, as well as develop policy mechanisms and techniques on preventing groundwater pollution. Figure 1 provides a schematic overview of the main components and outputs of the Pro Aquifer project. This paper is a result of the "scientific research" and "development of guidelines" phases of this project. The paper focuses on the scientific research component of the project and presents the findings of the research along with the main recommendations for groundwater protection guidelines for the Palestinian case study of Tulkarm City.

\section{Research Methodology}

\subsection{General}

The research methodology developed in this paper consists of several stages (Figure 2). As described in the figure, selection of the case study was based on a group of indicators, suggested by environment experts in the region. Upon selecting Tulkarm as the Palestinian case study, an intensive field and desk research was carried out for the collection of all required data (including geographical \& statistical data, pollution sources, etc.). The data were collected from field surveys and from several sources of data such as [3-6]. A GIS database was designed to organize this large amount of data, to analyze it, and to present it in the form of aesthetically pleasing maps. The solute transport model and vulnerability \& hazard mapping were actually carried out in parallel. In

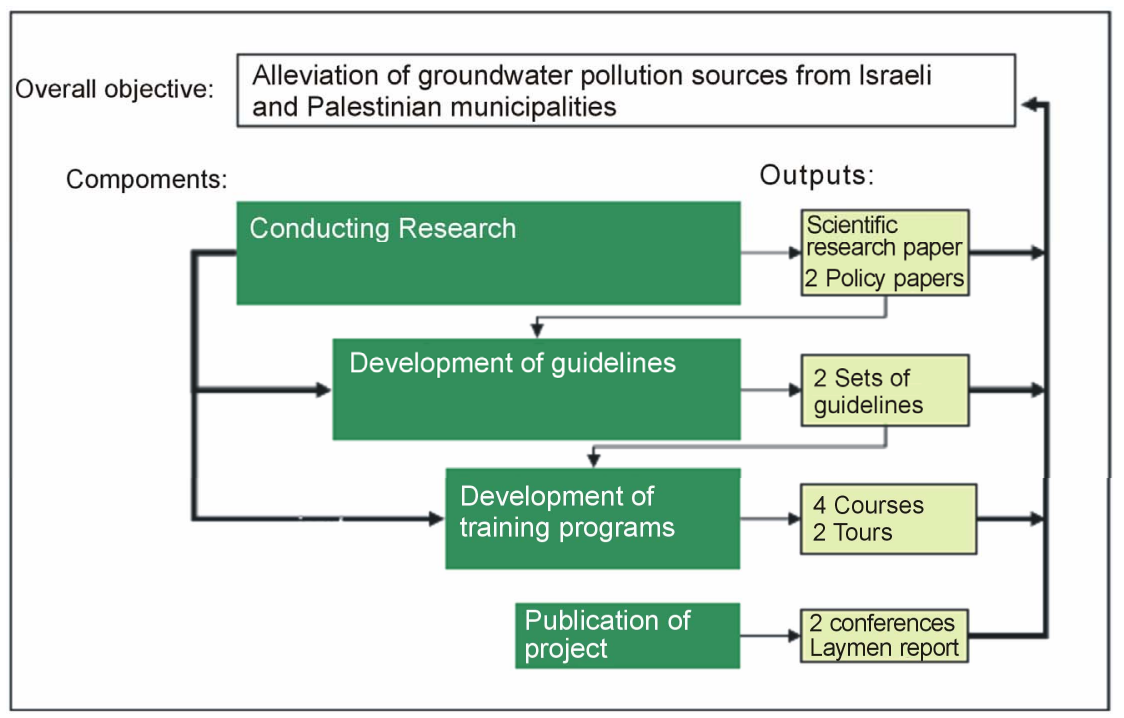

Figure 1. Schematic overview of the pro aquifer project.



Figure 2. Research methodology of this paper. 
the solute transport model, the model simulations were run for chloride as a conservative contaminant from wastewater wadi flow of Wadi Zeimar, a main sewage wadi running in Tulkarm. The vulnerability mapping will show the groundwater vulnerability in the study area, the hazard maps will show the location and intensity of hazards over the same area. A groundwater risk assessment will then be carried out to indicate the areas of highest groundwater risk.

\subsection{Selection of Case Study}

The first stage was the selection of a case study municipality for the research and the field work. The Palestinian municipality of Tulkarm was chosen. The selection was primarily based on the selection criteria proposed by the research team. These criteria included:

- Origin and type of pollution source;

- Hydro-geological sensitivity-degree of sensitivity of the aquifer to pollution from a certain locale/pollution source;

- Severity of pollution and risk of potential harm to aquifer;

- Potential ecological effects;

- Availability of data within municipality;

- Applicability of the policy model to other municipalities;

- Willingness of municipality to cooperate on project;

- Population trends.

Upon selecting the case study for this research (Tulkarem Municipality), the authors carried out a comprehensive literature review about the study area. The re- view included information obtained from technical \& scientific reports, government documents, and meetings with Tulkarm engineers and staff.

\subsection{Background of Tulkarm Study Area}

Tulkarm area (Figure $\mathbf{3}$ presents a location map) falls on the north-western strip (recharge area) of the Mountain Aquifer of the West Bank. This aquifer is presently the main source of drinking water for Palestinians in the West Bank. The recharge area is particularly vulnerable to pollution from sewage, solid waste, agricultural \& industrial pollution and other types of pollutants. The sensitivity is also attributed to the fact that the area of Tulkarm is also a location for groundwater utilization.

Sewage flow in the recharge area of the Mountain Aquifer leads directly to pollution of groundwater. Moreover, groundwater in that area is closer to the surface, requiring a shorter period of time for pollutants to percolate and reach it. Some of the most abundant water extractions from the Mountain Aquifer are located in that area. Alarmingly, it is also the location of some of the most serious pollution spots (Figure 4).

The geological formations of the Tulkarm governorate range in age from Upper Cretaceous to Quaternary. The district is mainly covered by sedimentary carbonate rocks such as limestone, dolomite, marl and chalk. The general geology of the Tulkarm area is represented in Figure 5.

The Upper Cenomanian formation (also known as the Bethlehem formation) consists of limestone, dolomite with chalk, and marl. The Turonian formation (also known as the Jerusalem formation) consists of a series of

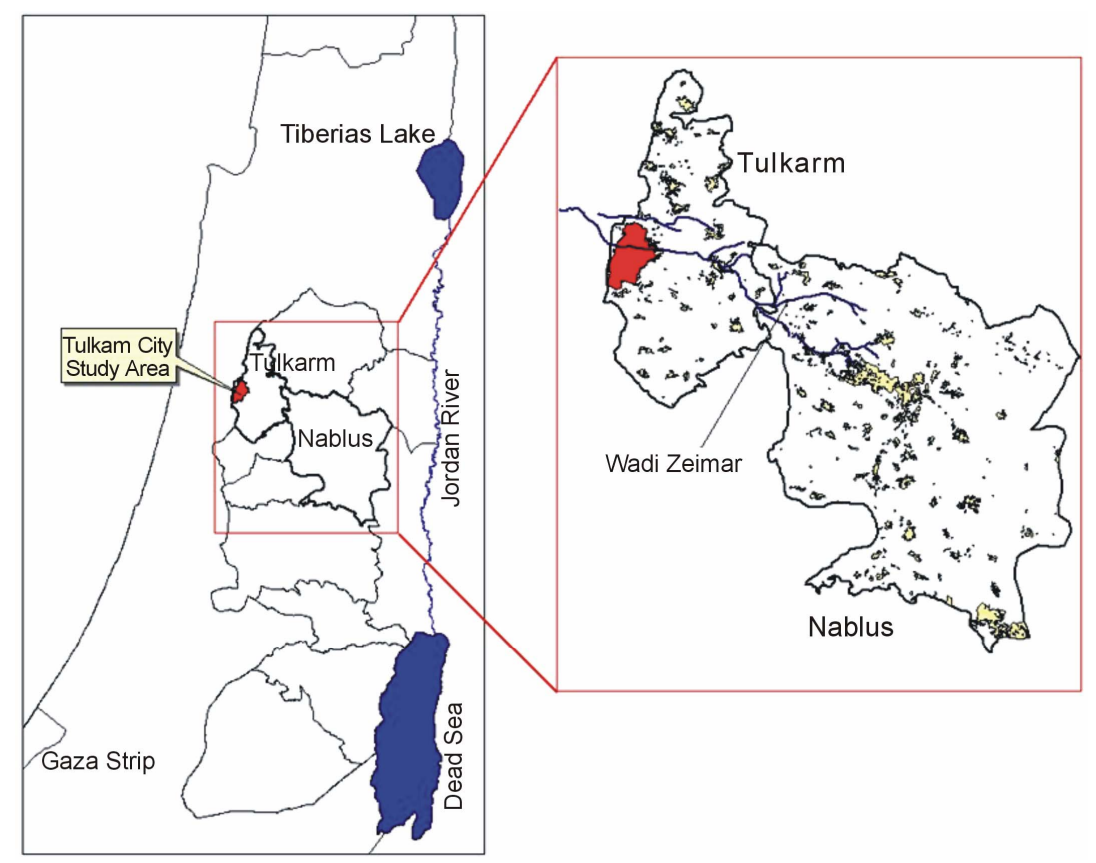

Figure 3. Location map of Tulkarm City (the study area). 


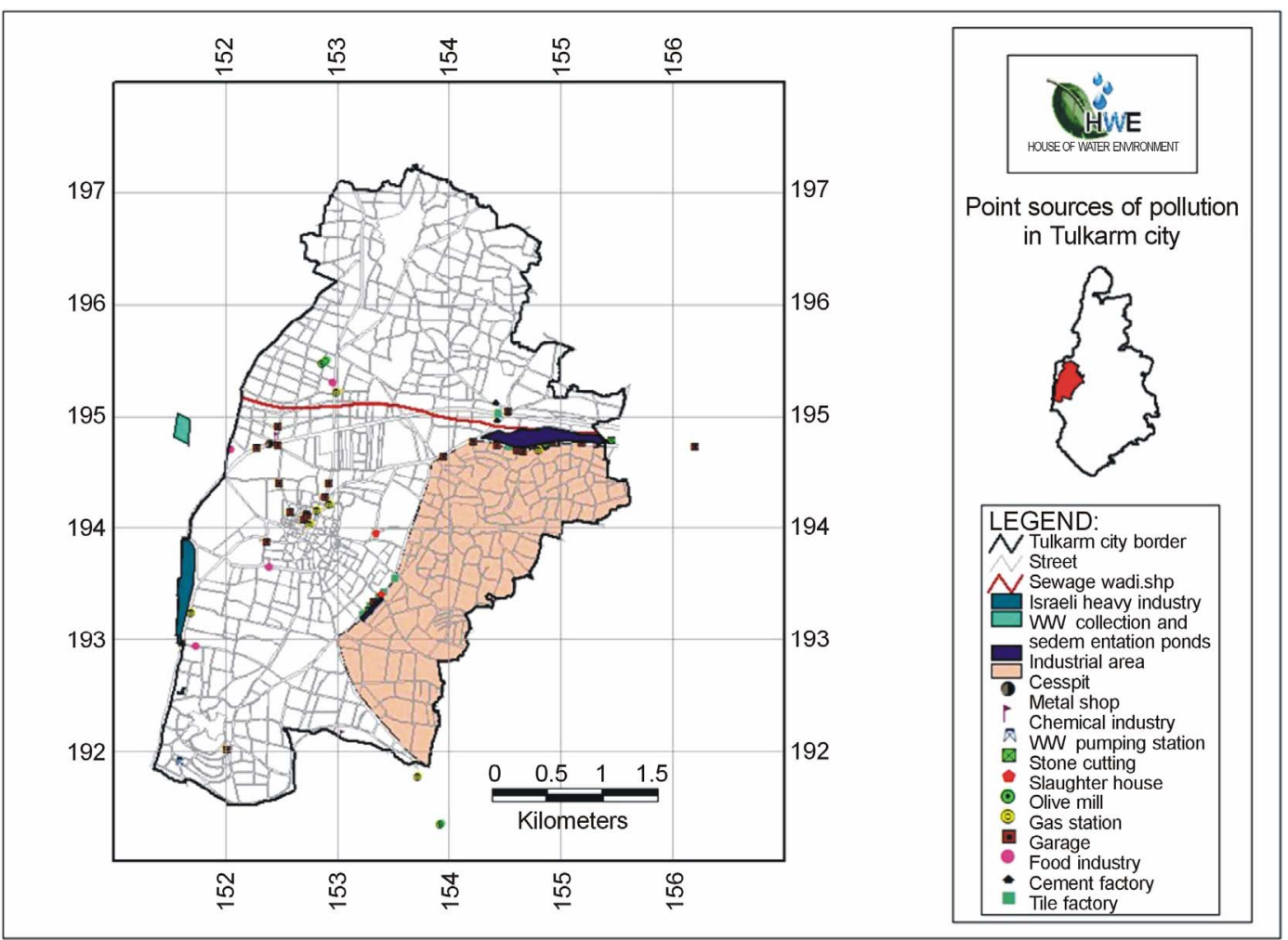

Figure 4. Map of pollution sources in Tulkarm City.

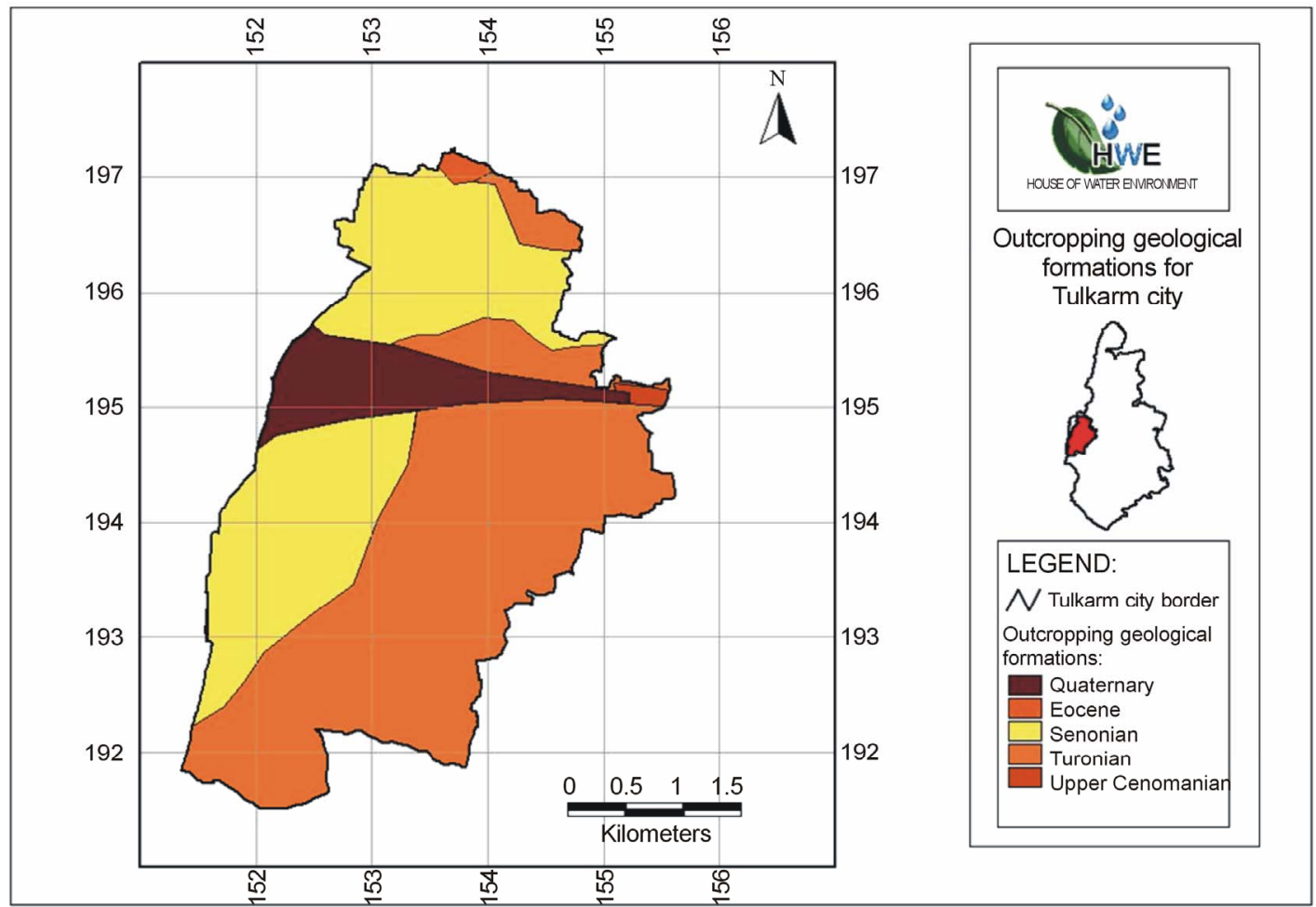

Figure 5. Outcropping formations in Tulkarm City.

massive, thick-to-thin bedded limestone to dolomitic limestone and dolomites with a thickness of approxi- mately 70 - $130 \mathrm{~m}$. The Turonian formation has a well-developed karst feature and is commonly used as a 
building stone. The Senonian formation is mainly made up of Cretaceous Rocks, which are composed of chalk. The chalk is thin and consists of marly base and passes upwards through bedded and crystalline limestone that has few marl partings. The Eocene formation is mainly composed of chalk and limestone. The presence of the limestone and the conglomerate lenses form a good aquifer while the chalk and marl act as a good aquiclude. Quaternary rocks are divided into 1) Lisan Formation: these recent sediments are mainly composed of alluvium consisting of limestone, chert and clay; and 2) Nari Formation: it occurs mainly in high rainfall areas where carbonate rocks are dissolved by percolating water $[7,8]$.

\subsection{Infrastructure}

Parts of the sewage collection network in Tulkarm city have been constructed since the rule of the Ottoman empire in the 1890's, are still in use to this day. Some areas of the city center are still served by clay channels which are still intact but suffer from cracks which cause leakage of wastewater to the ground. Wastewater generated by households is either transported by sewers to a central facility for sedimentation, pre-treatment and disposal or wastewater is disposed of on-site by the use of cesspits. Wastewater collection services (sewage networks) are available to about $75 \%$ of the localities within the Tulkarm municipality borders and refugee camps. The remaining 25\% are served with cesspits (as shown in Figure 4), the contents of which are pumped by tanker trucks, transported and dumped into wadi Zeimar and open areas, accompanied by large amounts of harmful bacteria, viruses and undesired microorganisms.

\subsection{GIS Database Design}

In addition to the desk study, the research team conducted a field survey to collect real data about the potential pollution sources in Tulkarm. Using geographic positioning system (GPS) devices and aerial photo maps, the team mapped the location of every pollution source in the city and produced GIS maps with a related database. Pollutants that were inventoried included: omestic wastewater, industrial wastewater from light and heavy Industries, solid waste, agricultural activities, organic waste, and other pollution from various human activities. Figure 4 shows a map of all pollution sources inventoried in Tulkarm City.

After producing the GIS database and GIS maps, an analysis of the impact of various pollution sources on the groundwater was carried out using the following tools: groundwater vulnerability assessment and mapping, hazard assessment and mapping, and risk assessment and mapping.

\section{Groundwater Vulnerability, Hazard and Risk Mapping}

Since aquifers in the Tulkarm area are karst aquifers, which are well known for their particular vulnerability to contamination arising from their special hydraulic characteristics, the Protection-Infiltration (PI) method [9] for vulnerability assessment was adopted. The PI method was specifically developed as a conceptual framework for mapping the vulnerability of karstic aquifers.

The PI Method is a GIS-based approach to mapping intrinsic groundwater vulnerability with special consideration of karst aquifers. This method has established a system for the mapping of intrinsic vulnerability of karst groundwater and for the characterization of the vulnerability of groundwater to specific contaminants or groups of contaminants. Finally, complete content and organizational editing before formatting. Please take note of the following items when proofreading spelling and grammar.

\subsection{Groundwater Vulnerability Assessment}

The PI factor, calculated within the PI-method (Figure 6), consists of the P-factor and the I-factor. The P-factor indicates the effectiveness of the protective cover and considers the soil field capacity, subsoil type, lithology type and fracturing, aquifer type and recharge conditions. The I-factor, which indicates the degree to which the protective cover is bypassed by lateral, surface and subsurface flow, considers the infiltration conditions and accordingly the flow concentration of the surface water. The final protection factor PI $(\pi)$ is the product of P and I. It is subdivided into five classes. A protective factor of $\pi$ $\leq 1$ indicates a very low degree of protection and an extreme vulnerability to contamination; $\pi=5$ indicates a high degree of protection and a very low vulnerability.

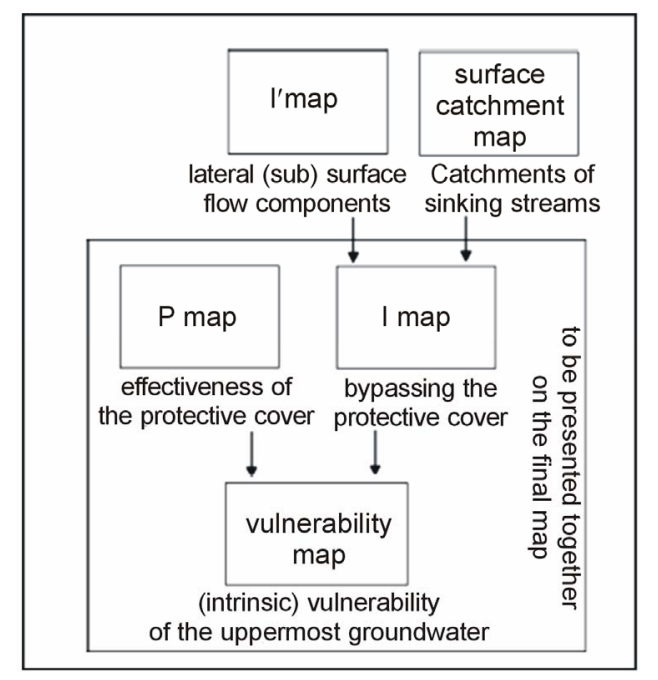

Figure 6. Simplified flow chart for the PI method. 
The spatial distribution of the $\pi$-factor is shown on the vulnerability map (Figure 7). A complete description of the procedure adopted, using the PI method is provided in [9].

The vulnerability map of Tulkarm (Figure 7) shows clearly that the majority of the study area is classified as moderate-high-extreme vulnerable to pollution. This means that any source of pollution, if disposed on these areas (red-brownish-yellow areas), then the contaminant will arrive at the groundwater system with a considerable strength and with a relatively shorter travel time. As a result, this will pose a serious risk to the groundwater aquifers.

\subsection{Hazard Assessment and Mapping}

An "environmental hazard" is formally defined as "an event, or continuing process, which if realized, will lead to circumstances having the potential to degrade, directly or indirectly, the quality of the environment". A hazard presents a risk when it is likely to affect something of value. Hazard Mapping is the preparation of hazard maps based on the Calculation of the Hazard Index (HI) - The hazard index describes the degree of harmfulness of each hazard. For its calculation the formula is:

$$
\mathbf{H I}=\mathbf{H} * \mathbf{Q} \mathbf{n} * \mathbf{R}_{\mathbf{f}}
$$

where: $\mathrm{HI}$ is the hazard index, $\mathrm{H}$ is the weighting value of each hazard-which describes the harmfulness of the hazard to the groundwater; Qn is the ranking factor $(0.8$ to 1.2), which considers the range of possible technical specifications of each hazard type; and $\mathrm{Rf}$ the reduction factor which considers the probability for a contamination event to occur. The hazard map for Tulkarm is presented in Figure 8.

The classified hazard map of Tulkarm city shows that the Israeli industrial zone is a high hazard and that the Palestinian industrial zone is a moderate hazard, and that can be understood by the type of industries on the Israeli side and the Palestinian side.

\subsection{Risk Assessment and Mapping}

The term "Risk" is used to describe the probability of suffering harm from a hazard. With regard to groundwater, it refers to the possible contamination as a result from a hazardous event. Risk maps show the risk of groundwater pollution of each hazard in relation to resource protection. The risk index is the probability that contaminants with a certain amount and concentration (intensity index) reach the surface of the groundwater. The groundwater and the aquifer characteristics are not included in this type of risk assessment. The risk intensity values are determined with an Equation (2):

$$
\mathbf{R I I}=\mathbf{1} / \mathbf{H I} * \pi
$$

$\mathrm{RII}=$ risk intensity index

$\mathrm{HI}=$ Hazard Index

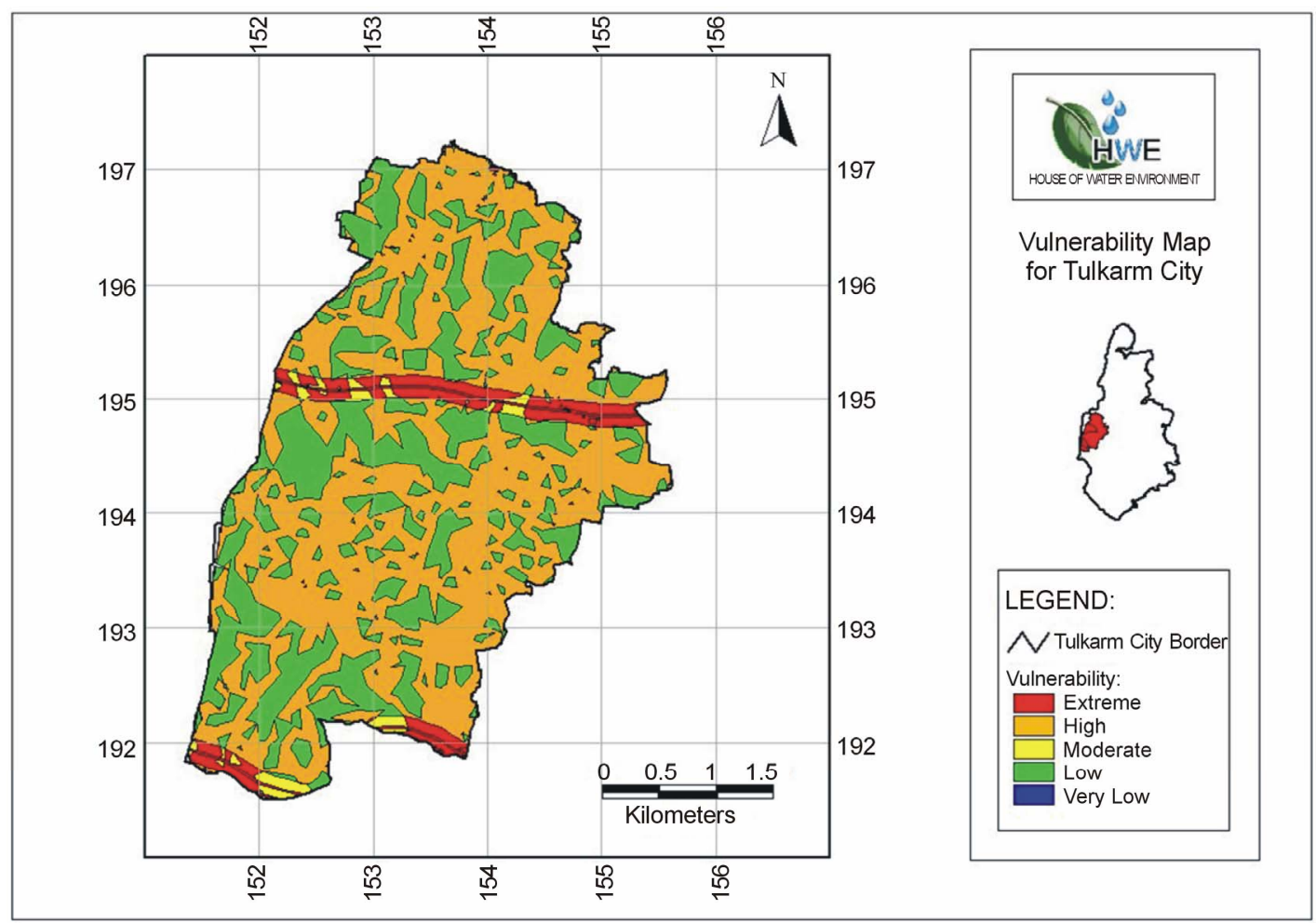

Figure 7. Vulnerability map of Tulkarm City. 


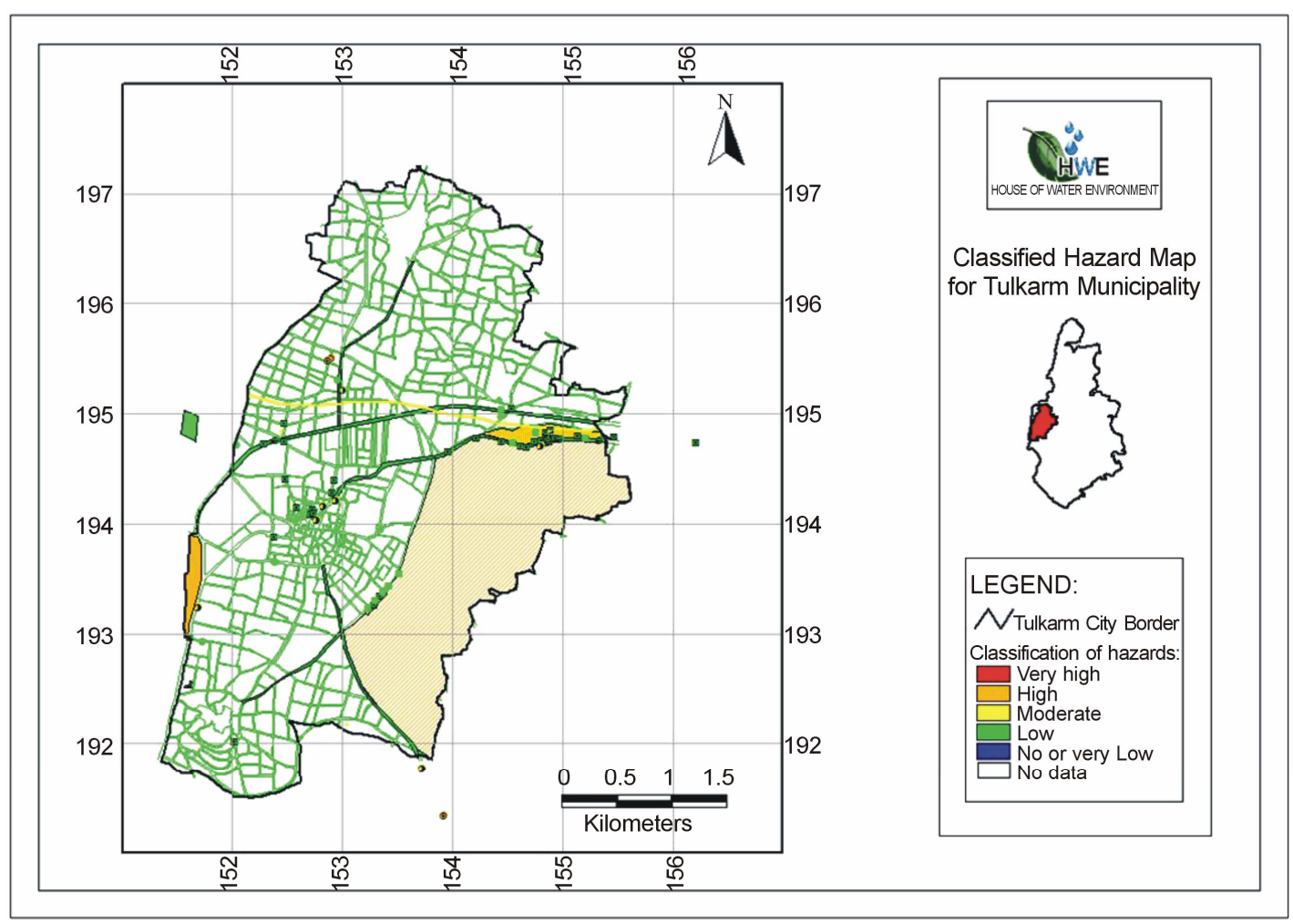

Figure 8. Classified hazard map of Tulkarm City.

\section{$\pi=$ PI-factor (index for intrinsic vulnerability)}

The proposed risk assessment is categorized by taking into account the classes of the vulnerability and the hazard index. This approach of risk assessment implies that hazards even with a low or very low hazard level could produce a "Very High" risk level if the vulnerability is very high. In comparison a hazard with a very high hazard level would produce only a "Moderate" or "High" risk level if the vulnerability is less than very high. Production of the hazard map is presented in Figure 9.

\section{Groundwater Flow and Contaminants Transport Model for Tulkarm}

The Western Aquifer Basin, which is a component of the Mountain Aquifer, is considered the most important basin that provides reasonable quantities of fresh water for Palestinians, and therefore, should be managed and protected from any potential adverse impacts that cause degradation in its water quality. One of these adverse impacts is pollution transport from the untreated wastewater of Wadi Zeimar, which flows from Nablus City to the Tulkarm area (as shown in Figure 3), passing over more than $20 \mathrm{~km}$. The average annual flow of this sewage wadi is estimated in the study area to be around 1.86 $\mathrm{MCM} / \mathrm{yr}$. There are big concerns regarding groundwater pollution from the untreated sewage water in this wadi by infiltration and percolation mechanisms. These concerns are the main reasons for developing a local-scale groundwater flow and pollution transport model for the Tulkarm area. Additionally, measurements for nitrate levels in the abandoned production well of "Anabta", which is located near Wadi Zeimar, have shown that nitrate levels in the groundwater in that well-exceed the WHO maximum limits for nitrate in drinking water1. This gives all the more reason to conduct a pollution transport for Wadi Zeimar.

The local-scale model was developed based on the regional flow model of the Western Aquifer Basin. The primary modeling objective of this model is to define, with as much accuracy and reliability as possible, the general characteristics of the groundwater flow system as well as to consequently assess the future transport trends of pollution in the groundwater water system of the Tulkarm area through developing a local-scale pollution transport model. Therefore, the model can act as a management tool to support the implementation of the necessary measures to protect and remediate the aquifer systems from any source of pollution, and determine the potential areas that might suffer from water quality problems.

The MODFLOW software was developed for heterogenous porous granular media, but certain features were managed in a way which takes into consideration the karstic nature of the study area. For example, in the calculation for transmissivity ( $\mathrm{T}$ ), the fact that $\mathrm{T}$ varies 

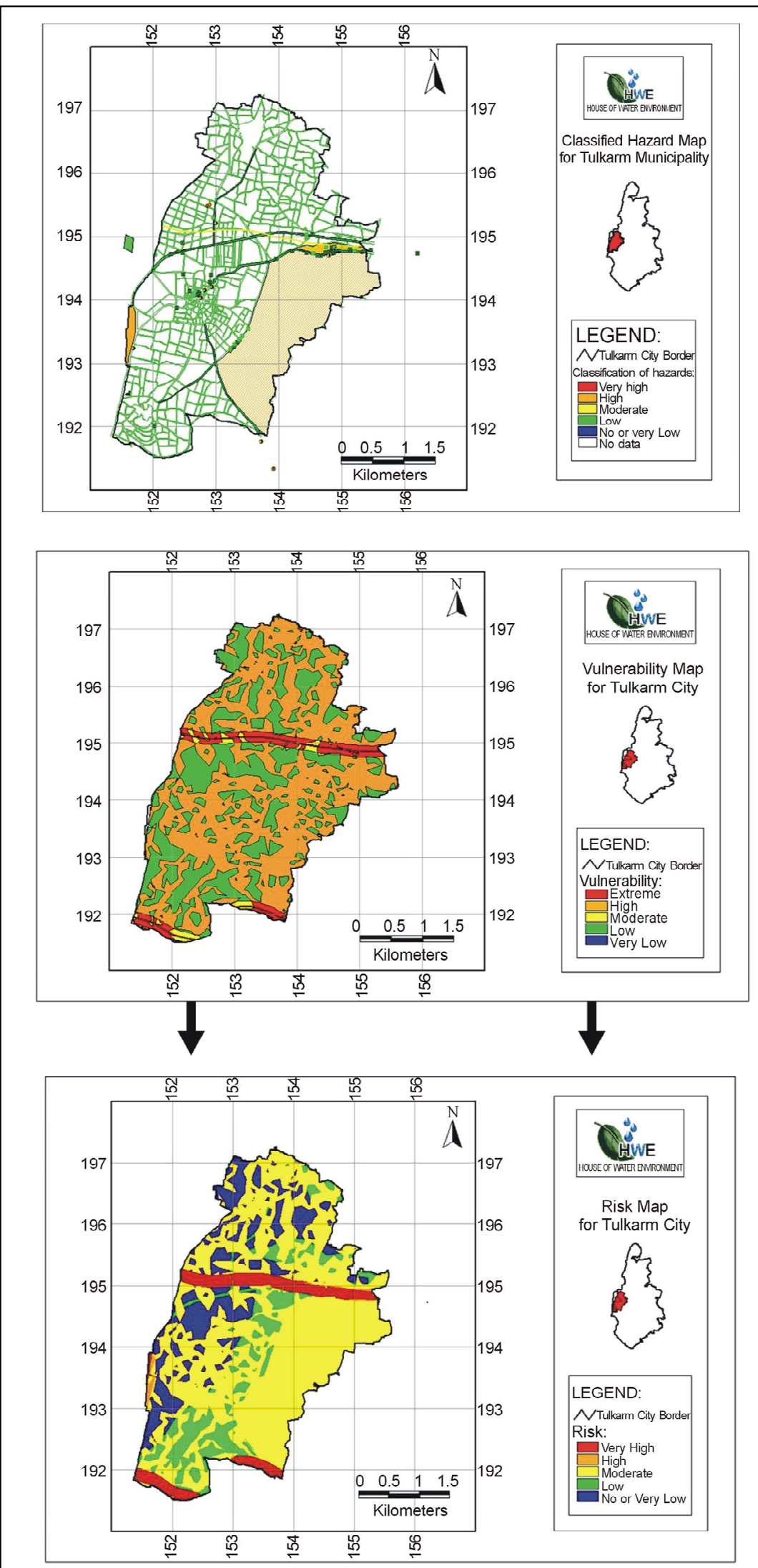

Figure 9. Hazard, vulnerability and risk maps for Tulkarm Municipality. 
widely from one section to another in karstic media was taken into consideration during the model calibration.

\subsection{The Groundwater Flow Model}

The model boundaries and domain were adapted based on the structural modified cross-sections of the study area, which show the lateral extent and outcropping of geologic formations, and groundwater flow direction. For this purpose, all available cross-sections, geological maps, and structural maps for the entire area were used to define the study area boundaries.

The conceptual model was created and translated into a numerical model automatically with the help of GMS module (MODFLOW), which will start running the model. The local-scale model domain was constructed based on the regional-scale model of the Western Aquifer Basin conducted by [10-13]. The grid is represented by 108 rows and 91 columns ( 9828 cells). The smallest cells in the grid are $10 \mathrm{~m}$ by $10 \mathrm{~m}$ and the largest cells are $1000 \mathrm{~m}$ by $1000 \mathrm{~m}$.

Layer data for the local-scale model, including aquifer hydraulic properties, were imported and interpolated from the regional model, and were subsequently adjusted and refined during calibration. At the end of the calibration process, the simulated hydraulic conductivity was characterized by low-range values from 10 to about 25 $\mathrm{m} /$ day. The simulated water table shows that 2 observation wells are less than 2 meters of difference. The simulated water budget of the aquifer system was analyzed to determine if the indicated sources and sinks of water were consistent with the conceptual hydrogeologic model.

\subsection{The Pollution Transport Model}

Once the flow model is calibrated against steady state condition, it can be used for contaminant simulation. This stage is considered the most important part since it simulates the transport behavior of pollutants within the aquifer system. The pollution model was launched automatically after steady-state simulation with the help of GMS module (MT3D). Flow and transport are better understood in the saturated zone than in the unsaturated zone, so transport in the saturated zone is modeled and assumed to be represented by single porosity media. The model simulations are run for chloride as a conservative contaminant from wastewater wadi flow of Zeimar. The pollution model is run for 6000 days to represent the spatial distribution of chloride plume within the aquifer system. Wadi Zeimar is the main source of pollution in the Tulkarm area. It provides an outlet for all the discharges of Nablus City, and passes more than $23 \mathrm{~km}$ to the western side of Tulkarm. This study will assess the impact of the untreated wastewater of Wadi Zeimer on the ground- water system of the Tulkarm area. The main parameter that is tested during the pollution model is the chloride, with concentration of $3019 \mathrm{ppm}$ in the untreated wastewater of Wadi Zeimar. The aquifer properties that control the movement and distribution of pollutants through groundwater are hydraulic properties which control the flow field and additional properties affecting the advective and dispersive movement of pollutants transport are porosity and dispersivity (in the transverse and longitudinal directions relative to flow).

\subsection{Model Simulations}

The results of pollution model indicate a general trend and distribution of pollution plume to east from Wadi Zeimar. The spatial distribution of concentration is parallel to the input source. The effects of pollution plume after 300 days cover an area of $9.0 \mathrm{~km}^{2}$, and about 14.0 $\mathrm{km}^{2}$ after 6000 days of simulation. The modeled groundwater velocities in the recharge zones of the aquifer are sufficient to carry pollutants by advective process. The simulated plume of chloride shows also a concentration ranged from 41 to $624 \mathrm{ppm}$ after 300 days, and therefore 4 wells will be affected by pollution plume. Meanwhile, the simulated plume of chloride concentration ranges from 91 to 1368 ppm after 6000 days and about 7 wells will be affected by the pollution plume. Figures 10 and $\mathbf{1 1}$ show the plan view simulations of the plume distribution within the aquifer system after 300 days and 6000 days, respectively. Figure 12 shows the side view simulation of plume after 6000 days.

\section{Research Results}

Following the adopted methodology [9], vulnerability, hazard, and risk maps were created for Tulkarm, as shown in Figure 9. The vulnerability map shows the intrinsic vulnerability and the natural protection of the uppermost aquifer. The classified hazard map portrays the areas or points at which activities lead to the degradation, directly or indirectly, of the quality of the environment. The risk map is used to describe the probability of suffering harm from a hazard. With regard to groundwater, it refers to the possible contamination as a result from a hazardous event.

From the final PI-map of Tulkarm, it was shown that about $4 \%$ of the study area is classified as extreme vulnerability, $38 \%$ as high, $28 \%$ as moderate, $17 \%$ as low and $13 \%$ as very low. Hence, Tulkarm city is classified as high-to-moderate vulnerability. The hazards in Tulkarm city represent Hazard Index Classes ranging from 1 to 3, therefore very low and low Hazard Levels dominate. The results from the risk map of the study area show that about $7.2 \%$ of the total area is classified as very high risk, $0.7 \%$ as high risk, $68.5 \%$ as moderate risk, $11.1 \%$ as low 


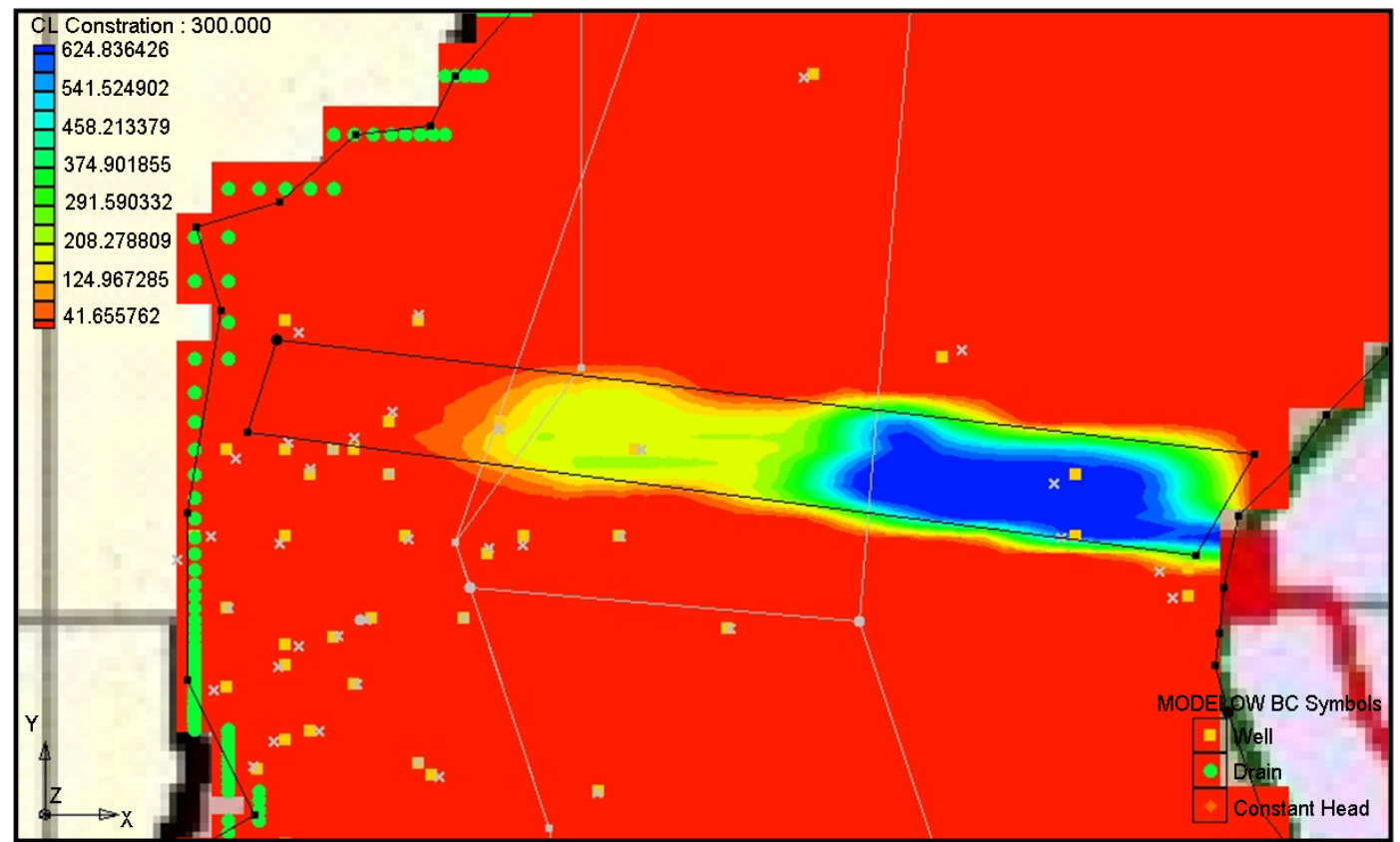

Figure 10. Chloride concentration (mg/L) after 300 days.

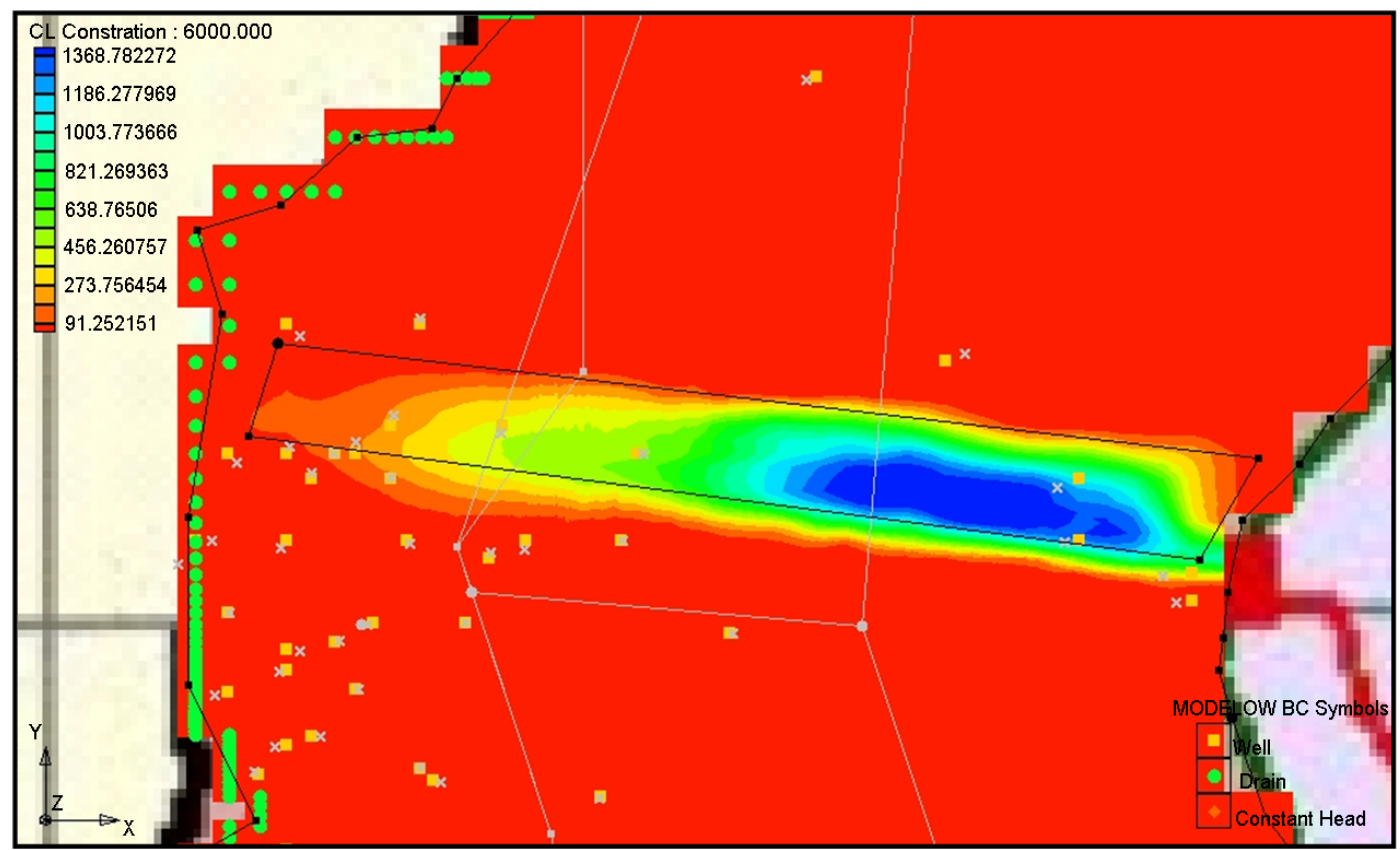

Figure 11. Chloride concentration (mg/L) after 6000 days.

risk and $12.5 \%$ as no or very low risk. Hence, the study area can be classified as a moderate risk area.

Hazards located in the highest risk areas (red) on the risk map should be addressed and remediated first. Potential hazards should be particularly avoided and prevented in this area. Hazards in the next greatest areas of risk should be addressed subsequently.

The results of the pollution model indicate a general trend of pollution plume to the east from Wadi Zeimar.
The effects of this pollution plume will reach to considerable areas. Within 300 days, the plume will occupy about $9.0 \mathrm{~km}^{2}$, while it will reach to more than $14.0 \mathrm{~km}^{2}$ after 6000 days. The simulated plume of chloride has concentration ranging from 41 to $624 \mathrm{ppm}$ after 300 days, so 4 wells will be affected by pollution. Meanwhile, the simulated plume of chloride ranges from 91 to $1368 \mathrm{ppm}$ after 6000 days and about 7 wells will be affected by the pollution plume. 


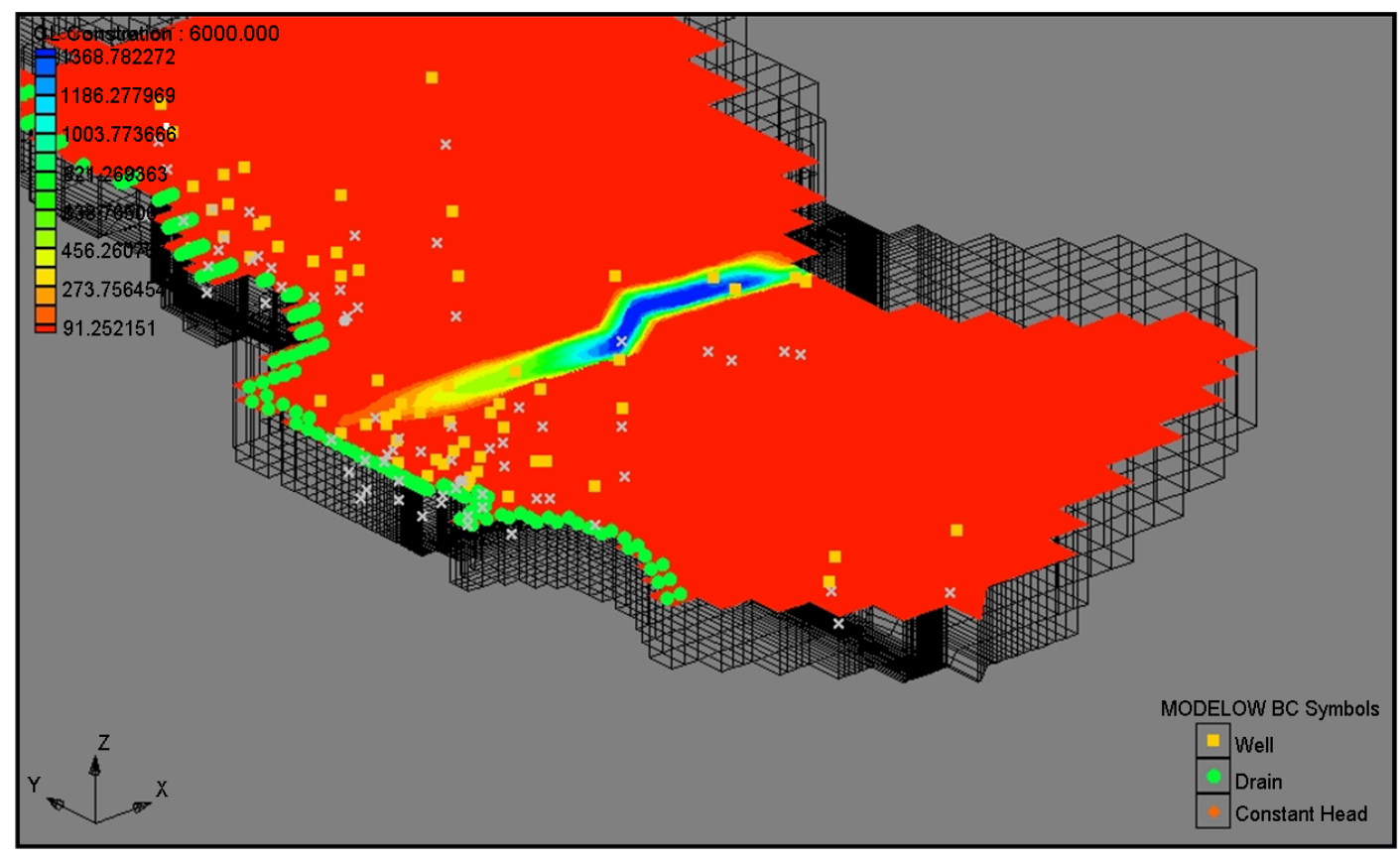

Figure 12. Side view of chloride concentration (mg/L) after 6000 days.

\section{Production of Guidelines for Municipalities}

This research has also produced policy recommendations to be implemented for the case study municipality of Tulkarm. These recommendations aim to help municipalities to prevent pollution of the critical trans-boundary groundwater resources that underlie the Mountain Aquifer, based on the findings and results of the general research and the vulnerability, hazard, and risk assessment and mapping carried out in this project. A guideline document was created for Palestinian municipalities, for the protection of groundwater from pollution sources based on the vulnerability, hazard, risk mapping and the pollution transport model, citing Tulkam as the case study municipality.

The guidelines and recommendations produced will provide a methodology to help municipalities begin solving the environmental issues they face. The goals of these recommendations are to protect and prevent further deterioration of the resources of the Mountain Aquifer and to enable and empower municipal officials and staff to achieve these goals. The approach used consists of seven steps. The first two steps form the basis of the Pro-Aquifer "toolkit" and the additional five steps serve as "generic" policy recommendations to help municipalities prevent groundwater pollution, and which comprise a third key component of the "Pro-Aquifer" toolkit. In brief, these steps are:

- Step 1: Conduct scientific and institutional research; and, use Geographic Information Systems (GIS) to prioritize threats to the Aquifer.

- Step 2: Provide training courses on relevant topics (e.g., sewage treatment management techniques) for municipal staff.

- Step 3: Develop a strategic plan to prevent groundwater pollution.

- Step 4: Enhance infrastructure.

- Step 5: Conduct inspections, monitoring, and enforcement.

- Step 6: Secure sustainable financing.

- Step 7: Improve education and awareness.

For Tulkarm, a series of detailed, short (1 - 2 years), medium ( $3-5$ years) and long term (5+ years) recommendations were developed. These recommendations include:

- Enhancing infrastructure, taking population growth into account, to improve solid waste collection and disposal/prevent illegal dumping, and to enhance sewage treatment;

- Expanding public education and awareness on local environmental conditions and on ways in which to protect the local, trans-boundary groundwater resources of the Mountain Aquifer, especially by working with youth, women, and NGOs.

- Increasing the municipality's institutional capacity to conduct inspections and monitoring of infrastructure and of businesses, and its capacity to enforce against environmental violations;

- Securing sustainable local financing, for example, by directing municipal taxes for water and sanitation back into operating, maintaining, and upgrading these systems;

- Developing a strategic plan to prevent groundwater pollution that incorporates a holistic approach, based 
on the concept and principles of Integrated Water Resources Management (IWRM);

- Improving coordination and communication among municipal departments to properly assign and address environmental hazards.

- Using GIS to share information among different departments and provide a common base of information for dialogue.

- Learning from other experiences in the region through cooperation and exchanging ideas and information.

\section{Conclusion}

This paper has shown the importance of protecting Palestinian water resources from pollution generated by municipalities and the importance of effectively managing these water resources. The general aim of this paper is to addresses the protection of groundwater resources from pollution from the unique perspective of local municipalities, in an attempt to help municipalities identify polluting activities in their boundaries, as well as develop policy mechanisms and techniques on preventing groundwater pollution. The modeling and vulnerability mapping assessment indicated that Tulkarm is located in a moderate to highly vulnerable area, due to the natural characteristics of the region. Sewage flow in the recharge area of the Mountain Aquifer leads directly to pollution of groundwater. Moreover, groundwater in that area is closer to the surface, requiring a shorter period of time for pollutants to percolate and reach it. Unfortunately, it is also the location of some of the most serious pollution spots. So, these areas are particularly vulnerable to pollution from sewage, solid waste, agriculture and other types of pollutants. The results of the pollution modeling indicate a general significant trend and distribution of a pollution plume because of raw sewage in wadi Zeimar in the Tulkarm area. The pollution plume covers $14 \mathrm{~km}^{2}$ in the Tulkarm area after 6000 days of model simulation. This will affect 7 groundwater wells in the area.

\section{Recommendations}

The outputs of this paper emphasize the need for more efforts to protect natural resources from pollution. It is recommended to take more cases of Palestinian municipalities and to study their sources of pollution and how they impact on the shared groundwater resources. In order for any comprehensive and integrated cooperative approaches to be successful, it is recommended to construct a comprehensive GIS database for pollution sources that covers all municipalities. Although data availability was an important indicator in the selection of the case study of Tulkarm, once the actual work took place, it was realized that some substantial data and information were still needed. It is recommended that reliable data should be available for all municipalities for future work. Pollution needs monitoring and real time data in order to alleviate its negative impacts on water resources. It is recommended to investigate one type of pollution (i.e. pollution generated from improper solid waste management practices), and to install monitoring equipment/structures to study the degree of pollution and then introduce a solution and use the same monitoring tool in order to see how much pollution can be alleviated. Groundwater pollution modeling for cities is highly recommended. This will help investigate the degree of spread of pollution on one hand and help investigate the effectiveness of any solution that will be introduced in the future. The scientific research and pollution modeling will help develop groundwater protection guidelines and/or standards. Both the results of the research and the groundwater protection guidelines should establish the material for further training and capacity building programs for municipalities.

\section{Acknowledgments}

The House of Water and Environment (HWE) would like to express their gratitude and appreciation to the European Commission-Environment DG-Life, and Green Cross-France for the generous support and funding, without which this project would not have been possible. HWE would also like to thank Friends of the EarthMiddle East and its team for their efforts.

\section{REFERENCES}

[1] Z. Tagar, T. Keinan and G. Bromberg, "A Seeping Timebomb: Pollution of the Mountain Aquifer by Sewage," Water Resources in the Middle East, Vol. 2, 2007, pp. 417-426. http://dx.doi.org/10.1007/978-3-540-69509-7_42

[2] A. Aliewi, K. Rajab, N. Imseih, J. Abu Sada, L. Freimuth and A. Saltman, "Protecting Trans-Boundary Groundwater Sources from Pollution: 'Research, Training and Guidelines for Municipalities'," House of Water and Environment, Palestine, and Friends of the Earth-Middle East, 2008.

[3] Central Bureau of Statistics (CBS)-Israel, "Environment Data Compendium," No. 2, 2006, pp. 7-9,59-61. http://www1.cbs.gov.il/www/hodaot2006n/envcompendiu m.pdf

[4] Central Bureau of Statistics (CBS)-Israel, "Labour Force Survey of 2006," No. 1305, 2008.

http://www1.cbs.gov.il/reader/y_labor/yearm_e_new.htm

[5] PCBS, "Projected Mid-Year Population in the Palestinian Territory by Governorate (2001-2007)," Palestinian Central Bureau of Statistics, 2006. http://www.pcbs.gov.ps/Portals/_pcbs/populati/demd1.aspx

[6] PCBS, "Distribution of Dumping Sites by Environmental Supervision Availability on the Dumping Site and Governorate in the Palestinian Territory," 2007. 
http://www.pcbs.gov.ps/Portals/_pcbs/Environment/statist _tab17.aspx

[7] Rofe and Raffety, "Nablus District Water Resources Survey, Geological and Hydrological Report," Hashemite Kingdom of Jordan, Central Water Authority, Rofe \& Raffety Consulting Engineers, Westminster, London, 1965.

[8] Rofe and Raffety, "West Bank Hydrology," Hashemite Kingdom of Jordan, Central Water Authority, Rofe \& Raffety Consulting Engineers, Westminster, London, 19631965.

[9] COST 620, "Vulnerability and Risk Mapping for the Protection of Carbonate (Karst) Aquifers, Final Report (COST Action 620)," European Commission, DirectoratGeneral XII Science, Research and Development, Brüssel, Luxemburg, 2003.

[10] SUSMAQ, "Local Groundwater Pollution Models for Tulkarem and Hebron. Sustainable Management of the
West Bank and Gaza Aquifers," Palestinian Water Authority (Palestine) and University of Newcastle, 2002.

[11] SUSMAQ, "Compiled Base Data for the Numerical Groundwater Flow Model of the Western Aquifer Basin," Sustainable Management of the West Bank \& Gaza Aquifers, Palestinian Water Authority \& University of Newcastle, 2003, 195 p.

[12] SUSMAQ, "Numerical Groundwater Flow Model of the Western Aquifer Basin," Sustainable Management of the West Bank \& Gaza Aquifers, Palestinian Water Authority University of Newcastle, 2004.

[13] SUSMAQ, "Numerical Regional Pollution Model of the Western Aquifer Basin," Sustainable Management of the West Bank \& Gaza Aquifers, Palestinian Water Authority \& University of Newcastle, 2005. 